\title{
PERAN PROGRAM ADIWIYATA MANDIRI DALAM MENINGKATKAN KEPEDULIAN LINGKUNGAN PESERTA DIDIK
}

\author{
Septi Rotari, Kokom Komalasari \\ Universitas Pendidikan Indonesia, Bandung \\ email: rotari17@gmail.com ${ }^{1,}$ komalasari110@yahoo.com ${ }^{2}$ \\ Naskah diterima: 20/04/2017 revisi: 27/04/2017 disetujui: 27/04/2017
}

\begin{abstract}
Abstrak
Penelitian bertujuan untuk mendeskripsikan program adiwiyata mandiri di sekolah dalam meningkatkan kepedulian lingkungan peserta didik, menganalisis implementasi program adiwiyata mandiri meningkatkan kepedulian lingkungan peserta didik, menganalisis kepedulian lingkungan peserta didik, mendeskripsikan kendala dan upaya implementasi program adiwiyata mandiri dalam meningkatkan kepedulian lingkungan peserta didik. Pendekatan menggunakan pendekatan kualitatif dengan metode studi kasus. Pengumpulan data menggunakan dokumentasi, wawancara, observasi. Data dianalisis dengan reduksi data, penyajian dan penarikan kesimpulan. Hasil penelitian menunjukkan, cara meningkatkan kepedulian dengan mengikutsertakan peserta didik dalam kegiatan penghijauan tanaman, melakukan pemilahan sampah, pengomposan dan memanfaatkan penggunaan lahan, pengimplementasian dilihat dari materi, motode, media, sumber dan penilaian yang dilakukan oleh guru dalam proses pembelajaran, pembiasaan yang dilakukan oleh peserta didik terhadap lingkungan kelas seperti menjaga kebersihan kelas pada saat proses pembelajaran serta merawat taman kelas.
\end{abstract}

Kata Kunci: Program Adiwiyata Mandiri, Kepedulian Lingkungan

\section{THE ROLE OF ADIWIYATA MANDIRI PROGRAM IN ENHANCING ENVIRONMENTAL AWARENESS LEARNER}

\begin{abstract}
The study aims to describe the independent adiwiyata program in schools in improving the environmental awareness of learners, analyzing the implementation of independent adiwiyata program to increase environmental awareness of learners, analyze environmental awareness of learners, describe the obstacles and efforts of independent adiwiyata program implementation in raising environmental awareness of learners. The approach uses a qualitative approach with case study methods. Data collection using documentation, interviews, observation. Data were analyzed by data reduction, presentation and conclusion. The result of the research shows how to increase awareness by involving students in planting activities, sorting waste, composting and utilizing land use, implementation of material, motod, media, source and assessment done by teacher in learning process, habituation done by Learners to the classroom environment such as maintaining the cleanliness of the classroom during the learning process and caring for the classroom garden.
\end{abstract}

Keywords: Adiwiyata Mandiri Program, Environmental Concern 


\section{PENDAHULUAN}

Masyarakat sekarang ini ikut dimanjakan oleh kemudahan-kemudahan dari hasil globalisasi, baik itu dalam bidang ilmu pengetahuan maupun teknologi (IPTEK). Sementara itu dapat kita pahami juga bahwa IPTEK dalam globalisasi memiliki dampak positif dan negatif. Dampak positif harus dapat dikembangkan sehingga dapat membantu kehidupan masyarakat secara kondusif. Namun sebaliknya, dampak negatif dari globalisasi tentunya harus dikurangi dan sebisa mungkin harus dapat dicegah agar tidak terjadi. Beberapa penyebab dari dampak negatif ketidak pedulian terhadap lingkungan dapat terjadi dikarenakan pencemaran udara oleh kendaraan bermotor, kurangnya lahan terbuka hijau dan juga kebiasaan membuang sampah sembarangan yang memang sudah menjadi rahasia umum (Iskandar, 2013:194). Contoh lainnya pada bulan September 2015 ini, banyaknya kebakaran lahan yang membuat pulau Sumatera dikepung kabut asap yang berkepanjangan. Sehingga banyak masyarakatnya terkena penyakit, kabut asap pun melumpuhkan infrastruktur perekonomian warga dan juga mengganggu jalannya pembelajaran peserta didik disekolah diakibatkan kabut asap, hal ini menjadi bukti bahwa kurangnya kesadaran masyarakat terhadap kepedulian lingkungan.

Melihat keadaan yang sekarang ini terjadi, masyarakat lebih rentan mengeksploitasi alam demi keuntungan pribadi. Hal ini tentunya berakibat fatal bagi masyarakat untuk kelangsungan hidup kedepannya. Sehingga apapun yang dilakukan oleh manusia terhadap lingkungan, dampaknya akan kembali kepada manusia itu sendiri, dan sampai sekarang dapat dilihat secara jelas bahwa masih kurangnya rasa kepedulian untuk merawat dan memelihara lingkungan oleh sebagian masyarakat. Kenyataan sekarang yang ada, masih banyak masyarakat yang tidak peduli dan tidak menghargai lingkungan. Tingkah laku seperti merusak lingkungan, korupsi, dan juga konflik yang tengah terjadi dewasa ini, pada dasarnya kurang dilakukannya suatu pengenalan nilainilai dengan baik di keluarga.

Selain dari lingkungan keluarga, lingkungan pendidikan turut serta menjadi wahana pembelajaran dalam menumbuhkan sikap kepedulian terhadap lingkungan bagi setiap anak. Pendidikan juga menjadi wadah mengembangkan pola pikir dan membentuk sikap peserta didik. Serta dapat menjadi jalan untuk memberikan pengetahuan, dan juga dapat membentuk sikap dan kepedulian masyarakat terhadap lingkungan yang diinginkan (Hamzah, 2013:13). Oleh karena itu, dalam lingkungan pendidikan salah satu mata pelajaran yang memiliki peran penting dan memiliki andil yang besar dalam membentuk sikap kepedulian terhadap lingkungan antara lain PKn. Dimana PKn dianggap mampu untuk merubah cara pandang dan perilaku warga negara dalam mengelola krisis yang ada di lingkungannya. Sikap kepedulian terhadap lingkungan ini dapat diindikasikan sebagai salah satu bentuk sikap dari warga negara yang baik, sehingga dapat kita diketahui juga bahwa warga negara yang baik ialah warga negara yang dapat mematuhi dan juga dapat melaksanakan hukum dan juga semua peraturan dan perundang-undangan, dengan rasa penuh tanggung jawab, tidak merusak lingkungan, tidak mencemari lingkungan, tidak mencemari air dan udara disekitar serta dapat memelihara serta memanfaatkan lingkungan secara bertanggung jawab (Azis dalam Azis dan Sapriya, 2011: 312).

PKn juga menjadi salah satu mata pelajaran yang diusungkan agar dapat membentuk karakter warga negara yang baik dan juga peduli terhadap lingkungan, serta terintegrasi dalam mata pelajaran PKn. Sebagaimana karakter yang dikembangkan oleh Kemendiknas (2011:3) terdiri atas "Religius, Jujur, Toleransi, Disiplin, Kerja keras, Kreatif, Mandiri, Demokratis, Rasa Ingin Tahu, Semangat Kebangsaan, Cinta Tanah Air, Menghargai Prestasi, Bersahabat/Komunikatif, Cinta Damai, Gemar Membaca, Peduli Lingkungan, Peduli Sosial, Tanggung Jawab". Jadi, dapat diketahui bahwa PKn juga memahami tentang karakter dari sikap kepedulian peserta didik terhadap lingkungan.

Pendidikan karakter bukan sekedar mengajarkan mana yang benar dan mana yang salah, lebih dari itu pendidikan karakter juga menanamkan kebiasaan tentang hal kepedulian terhadap lingkungan. . Untuk dapat membentuk peserta didik yang berkarakter dapat dilakukan dengan memberikan pengalaman positif yang sebanyak-banyaknya kepada peserta didik melalui pendidikan yang ada di sekolah. Pengalaman positif peserta didik tersebut dapat 
Citizenship Jurnal Pendidikan Pancasila dan Kewarganegaraan Vol 5 No 1 April 2017, hal 32-41

Avaliable online at : http://e-journal.unipma.ac.id/index.php/citizenship

p-ISSN: 2302-433Xp e-ISSN 2579-5740

diaplikasikan dari salah satu program yang diusung oleh Kementerian Lingkungan Hidup Republik Indonesia yaitu program pendidikan lingkungan hidup pada jenjang pendidikan dasar dan menengah melalui program Adiwiyata. Program Adiwiyata berkenaan dengan kepedulian lingkungan dan terintegrasi ke dalam seluruh mata pelajaran yang ada di SMP Negeri 13 termasuk pendidikan kewarganegaraan.

Dan untuk mencapai tujuan program Adiwiyata, maka ditetapkan empat komponen program yang menjadi satu kesatuan utuh dalam mencapai sekolah Adiwiyata, keempat komponen tersebut adalah, kebijakan berwawasan lingkungan, pelaksanaan kurikulum berbasis lingkungan, kegiatan lingkungan berbasis partisipatif, pengelolaan sarana pendukung ramah lingkungan. Maka dari itu, penelitian ini bertujuan untuk mengkaji mengenai "Bagaimana Peran Program Adiwiyata Mandiri dalam Meningkatkan Kepedulian Lingkungan Peserta Didik (Studi Kasus di SMP Negeri 13 Kota Palembang)".

\section{METODE}

Metode penelitian yang digunakan pada penelitian ini menggunakan penelitian studi kasus, yaitu suatu metode penelitian yang memfokuskan pada satu fenomena yang dipilih. Hal ini senada dengan yang dikemukakan oleh Sukmadinata (2011, hlm. 99) bahwa penelitian studi kasus merupakan penelitian yang memfokuskan pada satu fenomena saja yang dipilih dan ingin dipahami secara mendalam, dengan mengabaikan fenomena lainnya dan fenomena tersebut bisa berupa seorang pemimpin sekolah, sekelompok siswa, suatu program, suatu proses, suatu penerapan kebijkan atau suatu konsep.

Al Muchtar (2014, hlm. 431) mengatakan bahwa studi kasus merupakan suatu peristiwa atau kejadian dalam masyarakat, yang sangat menarik perhatian karena memuat misteri dan menuntut untuk segera diungkap untuk memperoleh kebenaran di balik peristiwa tersebut. Jadi, dapat, ditarik kesimpulan bahwa pendekatan kualitatif dengan studi kasus merupakan suatu fenomena baik dari suatu program atau satu penerapan kebijakan yang sangat menarik, maka dari itu peneliti tertarik meneliti judul tersebut dengan pendekatan kualitatif dengan metode studi kasus.

\section{Jenis Penelitian}

Jenis penelitian ini menggunakan penelitian kualitatif, seperti yang diungkapkan oleh Sukmadinata (2007, hlm.60) bahwa penelitian kualitatif adalah penelitian yang ditujukan untuk mendeskripsikan dan menganalisis fenomena, peristiwa, aktifitas sosial, sikap kepercayaan, persepsi, pemikiran orang secara individual maupun kelompok. Selain itu, menurut Moleong (2003, hlm.3) mengemukakan bahwa penelitian kualitatif merupakan prosedur penelitian yang menghasilkan data kualitatif berupa katakata tertulis maupun lisan dan perilaku orang-orang yang diamati.

Selanjutnya menurut Craswell (2012, hlm.4) mengatakan pendekatan kualitatif adalah metode-metode untuk mengeksplorasi dan memahami makna yang oleh sejumlah individu atau sekelompok orang diangap berasal dari masalah sosial atau kemanusiaan. Berikutnya diungkapkan oleh Muchtar (2015) adalah penelitian yang bertujuan mencari kebenaran alamiah bukan kebenaran ilmiah. Dalam hal ini, penelitian kualitatif diarahkan untuk dapat mencari suatu kebenaran yang alamiah dan juga dapat mengkonstruksikan makna beserta nilai dari suatu situs penelitian. Oleh karena itu dalam melakukan suatu penelitian, peneliti mengumpulkan data berdasarkan observasi situasi yang wajar, sebagaimana adanya, dan juga tanpa sengaja.

\section{Waktu dan Tempat Penelitian}

Tempat penelitian yang dituju oleh peneliti untuk mendapatkan informasi, berdasarkan pertimbangan dari teori substantif. Sehingga membuat penelitian ini dilakukan di SMP Negeri 13 Kota Palembang, Provinsi Sumatera Selatan sebagai tempat penelitian. Sukardi (2004, hlm.53) mengemukakan bahwa tempat penelitian merupakan tempat di mana proses studi yang digunakan untuk memperoleh pemecahan masalah penelitian berlangsung. 
Terdapat beberapa alasan yang mendasari pemilihan SMP Negeri 13 Kota Palembang. Pertama, SMP Negeri 13 Kota Palembang menjadi salah sekolah di Indonesia yang mendapatkan penghargaan Adiwiyata Mandiri untuk tahun 2015. Kedua, Pemanfaatan lahan sekolah yang minim menjadi daya tarik dari SMP Negeri 13 Kota Palembang mendapatkan penghargaan program adiwiyata mandiri.

\section{Target/Subjek Penelitian}

Pada penetapan informan atau subjek penelitian dibutuhkan suatu kriteria dalam mengumpulkan sumber data penelitian. Hal ini senada dengan yang dikemukan oleh Miles dan Huberman (2007, hlm. 57) mengungkapkan beberapa kriteria yang dapat digunakan yaitu: latar (setting), para pelaku (actors), peristiwa-peristiwa (event), dan proses (process). Dari pendapat diatas dapat dipahami bahwa bentuk dari pengumpulan sumber data dalam penelitian, mencangkup pelaku atau manusia dan peristiwa yang sedang terjadi menjadi sumber data pada penelitian. Manusia pada penelitian kualitatif menjadi sumber data dan juga sebagai informan dari suatu peristiwa atau fenomena yang sedang berlangsung.

Untuk mendapatkan informasi mengenai masalah-masalah penelitian, maka digunakan teknik untuk mendapatkan informan yang jelas dan juga berkualitas. Maka peneliti menggunakan pengambilan sampel berdasarkan sumber data tertentu, Sugiyono (2009, hlm. 216) menjelaskan dalam penentuan informan menggunakan teknik purposive sampling yaitu adalah teknik pengambilan sampel sumber data berdasarkan pertimbangan tertentu. Pertimbangan tertentu dalam hal ini yaitu pengambilan informan berdasarkan pada pertimbangan pribadi dari peneliti sesuai dengan permasalahan yang akan dikaji. Adapun yang menjadi informan penelitian kali ini adalah Kepala sekolah, Guru, Siswa di SMP Negeri 13 Palembang yang telah mendapatkan penghargaan pada Program Adiwiyata Mandiri.

\section{Prosedur}

Adapun prosedur data yang digunakan dalam penelitian ini antara lain:

\section{Observasi}

Pengamatan ataupun juga observasi merupakan unsur yang penting dalam penelitian kualitatif. Dimana dengan menggukan teknik ini peneliti dapat memperoleh gambaran yang jelas mengenai masalah yang akan diteliti. Sebagaimana menurut Sutrisno Hadi dalam (Sugiyono, 2015, hlm. 203) mengemukakan bahwa "obeservasi merupakan suatu proses yang kompleks, suatu proses yang tersusun dari berbagai proses biologis dan psikologis, dua diantara yang terpenting adalah prosesproses pengamatan dan ingatan.

Obeservasi yang dilakukan oleh peneliti untuk memperoleh gambaran secara langsung tentang peran dari program Adiwiyata dalam meningkatkan Kepedulian lingkungan siswa SMP Negeri 13 di Kota Palembang. Oleh sebab itu, peneliti melalui obeservasi diharapkan dapat mengumpulkan informasi secara lebih mendalam.

Teknik ini dilakukan guna melakukan pengamatan langsung terhadap peran dari Program Adiwiyata Mandiri melalui pembelajaran PKn dalam meningkatkan kepedulian peserta didik terhadap lingkungan. Selain itu juga peneliti berusaha melihat apakah terdapat peningkatan dari program tersebut melalui pembelajaran PKn pada kepedulian peserta didik terhadap lingkungan.

\section{Wawancara}

Sukmadinata (2012, hlm. 216) mengemukakan bahwa, wawancara merupakan salah satu bentuk teknik pengumpulan data yang banyak digunakan dalam penelitian deskriptif kualitatif dan deskriptif kuantitatif. Senada dengan pendapat Cresswell (2010, hlm. 267) bahwa, wawancara dalam kualitatif, peneliti dapat melakukan wawancara berhadap-hadapan, dengan partisipan dan wawancara seperti ini tentu memerlukan pertanyaan-pertanyaan 
yang secara umum tidak terstruktur dan bersifat terbuka yang dirancang untuk memunculkan pandangan dan opini dari partisipan. Peneliti menggunakan teknik pengumpulan data ini agar data yang diperoleh dapat dipercaya dan lebih mendalam.

Dalam penelitian ini peneliti bermaksud melakukan wawancara dengan kepala sekolah, guru dan peserta didik di SMP Negeri 13 Palembang berkenaan dengan kepedulian lingkungan dan juga sekolah tersebut mendapatkan Adiwiyata pada tahun 2015 ini. Peneliti bermaksud mendapatkan informasi secara detail dari kepala sekolah, guru dan peserta didik tentang bagaimana sekolah tersebut mendapatkan Adiwiyata dan juga peran serta dari sekolah tersebut bagaimana menumbuhkan dan meningkatkan rasa atau sikap kepedulian lingkungan bagi peserta didik.

\section{Studi Dokumentasi}

Studi dokumentasi merupakan suatu teknik pengumpulan data yang digunakan dalam penelitian kualitatif yang digunakan untuk mencari informasi dari berbagai sumber yang memilki kaitan dengan kajian yang diteliti oleh peneliti. Sebagaimana menurut Arikunto (1998, hlm. 236) bahwa studi dokumentasi merupakan suatu teknik yang digunakan dan mencari data mengenai hal-hal atau catatan, buku-buku, surat kabar, prasasti, kajian kurikulum. Pada penelitian ini studi dokumentasi ini menjadi suatu yang sangat penting dimana sebagai pelengkap metode observasi dan juga wawancara berupa catatan lapangan, semesntara itu mendapat berbagai data mengenai program Adiwiyata disetiap SMP yang pernah mendapatkannya.

\section{Teknik Analisa Data}

Pengolahan data dalam penelitian kualitatif melalui suatu proses menyusun, mengkategorikan data, dan mengaitkan isi berbagai data yang dipeoleh dengan maksud untuk mendapatkan maknanya. Data yang dikumpulkan dan diperoleh dari responden melalui wawancara, observasi, studi dokumentasi dilapangan selanjutnya dideskripsikan dalam bentuk laporan.

1. Reduksi data, merupakan proses pemilihan, pemusatan perhatian pada penyederhanaan, pengabstrakan dan transfromasi data "kasar" yang muncul dari catatan-catatan tertulis di lapangan, reduksi data bertujuan untuk mempermudah pemahaman terhadap data yang terkumpul dari hasil catatan lapangan dengan cara merangkum dan mengklasifikasi sesuai dnegan masalah yang diteliti.

2. Penyajian Data, merupakan informasi yang tersusun yang member kemungkinan adanya penarikan kesimpulan dan pengambilan tindakan. Dan dengan melihat penyajian-penyajiannya peneliti dapat memahami apa yang sedang terjadi dan apa yang harus dilakukan, lebih jauh menganalisis ataukah mengambil tindakan berdasarkan atas pemahaman yang didapat dari penyajian-penyajian tersebut.

3. Menarik kesimpulan/verivikasi, yaitu mencari makna, penjelasan yang dilakukan terhadap data yang dikumpulkan dengan mencari hal-hal yang penting. (Miles dan Huberman, 1992: 16-18)

\section{HASIL PENELITIAN DAN PEMBAHASAN}

\section{Program Adiwiyata Mandiri di sekolah dalam meningkatkan kepedulian peserta didik terhadap lingkungan}

Berdasarkan dari proses pengumpulan data studi dokumentasi, wawancara dan observasi yang telah dilakukan oleh peneliti di SMP Negeri 13 kota Palembang adapun yang berhubungan dengan Program Adiwiyata Mandiri di sekolah dalam meningkatkan kepedulian peserta didik terhadap lingkungan diuraikan sebagai berikut:

Dari hasil observasi langsung yang telah dilakukan oleh peneliti terhadap peran 
program adiwiyata mandiri di sekolah dalam meningkatkan kepedulian peserta didik terhadap lingkungan, dapat dilihat dari visi SMP Negeri 13 Palembang yaitu menjadikan sekolah yang berilmu, berakhlaq mulia, berbudaya dan berwawasan Lingkungan. Hal ini juga sejalan dengan yang diinginkan oleh peserta didik yaitu untuk memiliki lingkungan sekolah yang asri dan juga bersih.

Merujuk pada hasil observasi langsung terhadap program adiwiyata mandiri di sekolah, didapatkan bahwa tindakan yang dilakukan oleh SMP Negeri 13 kota Palembang dalam meningkatakan kepedulian peserta didik terhadap lingkungan memperlihatkan bahwa program tersebut mengajak seluruh warga di SMP Negeri 13 kota Palembang untuk melakukan tindakan pemanfaatan lahan dan juga penghijauan kembali tanaman yang ada disekolah. Bukan hanya itu saja pada observasi langsung dilapangan banyak peserta didik yang melakukan pembibitan terhadap tanaman serta menggunakan kembali limbah dari air wudhu atau air hujan.

Beberapa hasil kesimpulan yang dapat ditarik oleh peneliti terhadap observasi dan juga terhadap informan bahwasanya, bagaimana peran program adiwiyata disekolah dalam meningkatkan kepedulian peserta didik terhadap lingkungan dapat dilakukan dengan berbagai macam upaya yang dilakukan sekolah, yaitu melakukan kembali pemanfaatan lahan yang ada, melakukan penghijauan tanaman, pemanfaatan kembali barang bekas dan melakukan pembibitan. Kemudian dari implementasi dari program adiwiyata mandiri disekolah kembali mengajak peserta didik bersama dengan para guru melakukan penghijauan tanaman dan dari kegiatan piket umum serta piket kelas, mengajak peserta didik untuk melakukan pemilihan sampah serta sampai pada kegiatan pengomposan dilakukan oleh peserta didik. Namun jika dilihat dari kendala,ada beberapa guru yang tidak menyetujui kegiatan dari program adiwiyata ini atau dapat dikatakan kendala secara internal serta kendalanya juga masih sangat kurang rasa kesadaran dari peserta didik untuk peduli terhadap lingkungan.

$$
\text { Upaya yang dilakukan dalam }
$$

menerapkan program adiwiyata mandiri dalam meningkatkan kepedulian peserta didik terhadap lingkungan, dilakukan oleh guru dengan cara selalu mengingatkan kepada peserta didik baik itu dalam lingkungan sekolah atau pun kelas baik itu disampaikan secara langsung atau pun tidak langsung, serta pemberian contoh secara langsung yang dilakukan oleh guru untuk memberikan pembelajaran kepada peserta didiknya untuk memiliki kepedulian terhadap lingkungan dengan melihat tindakan atau contoh langsung yang dilakukan oleh para gurunya tersebut. Kegiatan tersebut antara lain melakukan pembibitan, merawat dan menjaga tanaman, ikut melaksanakan pengomposan menjadi program adiwiyata mandiri disekolah dalam meningkatkan kepedulian peserta didik terhadap lingkungan.

Dijelaskan bahwa SMP Negeri 13 kota Palembang ini merupakan sekolah negeri yang mendapatkan penghargaan dari program adiwiyata. Program adiwiyata ini merupakan program yang dicanangkan oleh pemerintah yang diperuntuhkan untuk seluruh sekolah. Program adiwiyata ini merupakan program yang dapat memupuk dan menjadikan sekolah yang berwawasan lingkungan. Untuk mendapatkan program adiwiyata mandiri ini harus melalui beberapa tahapan, antara lain adiwiyata kota, adiwiyata provinsi, adiwiyata nasional dan adiwiyata mandiri. Kemudian salah satu syarat agar sekolah tersebut mendapatkan penghargaan adiwiyata antara lain harus memiliki visi dan misi sekolah yang berwawasan dengan lingkungan, hal ini pula yang membuat SMP Negeri 13 kota Palembang melakukan upaya agar mendapatkan penghargaan adiwiyata, salah satunya visi sekolah yaitu menjadikan sekolah yang berilmu, berakhlaq mulia, berbudaya dan berwawasan Lingkungan. Selanjutnya melakukan pembibitan di lahan minim, dan juga pemanfaatan limbah air 
hujan yang digunakan sebagai langkah awal dari pencapaian penghargaan untuk mendapatkan program adiwiyata mandiri.

Program adiwiyata merupakan program yang berwawasan lingkungan yang diperuntuhkan bagi peserta didik untuk turut berpastisipasi dan memiliki wawasan terhadap lingkungan. Sehingga, program adiwiyata mandiri yang diterapkan disekolah memupuk peserta didik untuk peduli terhadap lingkungan. Sebagaimana karakter yang dikembangkan oleh Kemendiknas (2011, hlm. 3) terdiri atas "Religius, Jujur, Toleransi, Disiplin, Kerja keras, Kreatif, Mandiri, Demokratis, Rasa Ingin Tahu, Semangat Kebangsaan, Cinta Tanah Air, Menghargai Prestasi, Bersahabat/Komunikatif, Cinta Damai, Gemar Membaca, Peduli Lingkungan, Peduli Sosial, Tanggung Jawab.

Selanjutnya berdasarkan hasil penelitian dan juga penjabaran yang telah dimuat dalam tabel 4.1 triangulasi sumber dan tabel 4.2 triangulasi teknik. Menunjukkan bahwa Program Adiwiyata Mandiri di sekolah dalam meningkatkan kepedulian peserta didik terhadap lingkungan yaitu kesimpulan bahwa program adiwiyata mandiri disekolah dalam meningkatkan kepedulian peserta didik terhadap lingkungan, membutuhkan upaya yang dilakukan oleh guru. Guru juga memiliki andil yang cukup besar dalam memupuk dan juga meningkatkan kepedulian peserta didik terhadap lingkungan. Sebagaimana tindakan dari guru untuk mengingatkan dan juga memberikan contoh langsung kepada peserta didik akan pentingnya kepedulian lingkungan. Seperti halnya melakukan pembibitan tanaman, melakukan penghijauan dan juga melakukan pengomposan menjadi bagian dari program adiwiyata mandiri yang dilakukan secara bersama-sama. Menurut Taylor dan Francis (2009, hlm. 1) mengemukakan bahwa:

Environmental education research focusing on individual participants might also help us to understand increases in human capital and individual well-being not necessarily aimed at environmental or social change (e.g., increases in academic achievement through hands-on environmental education, and in mental and physical health as a result of exposure to nature).

Pendapat diatas juga menegaskan bahwa dibutuhkan juga partisipasi dari setiap individu untuk memahami lingkungan sehingga terjadi perubahan. Hal tersebut dapat diselarasakan dari kegiatan yang dilakukan oleh guru kepada peserta didik dengan cara mengingatkan dan juga memberikan contoh secara langsung atau habituasi. Selaras dengan yang dikemukakan oleh Parwono (2013, hlm. 15) menjelaskan bahwa guru selalu menanamkan cara-cara yang dapat memberi kebaikan pada kehidupan sosial dan lingkungan hidup, dimana peserta didik dapat menerima dengan baik serta dapat menerapkannya dalam kehidupan nyata sehari-hari di lingkungan sekolahnya. Program adiwiyata juga merupakan program yang berwawasan lingkungan, menginginkan agar peserta didik memiliki nilai kepedulian lingkungan.

Kemudian menurut Dutcher (2007, Hlm. 489) menjelaskan bahwa:

Connectivity is not only about seeing the environmental as part of ourselves but also about seeing ourselves as part of the environmental. Conetivity with nature refleks a sense of empathy because of the unity/communication between self and mature that is inherent in the concept.

Berangkat dari pendapat diatas menjelaskan lebih dalam lagi bahwa kesinambungan antara lingkungan dan juga diri, sangat diperlukan. Maka dari itu, program adiwiyata merupakan program yang mengusung agar peserta didik turut memiliki kepedulian terhadap lingkungan. Bukan hanya lingkungan di kelas, tetapi di sekolah dan juga dilaingkungan masyarakat atau sekitar. Program ini memiliki misi positif yang tidak hanya diperuntuhkan untuk peserta didik saja, tetapi juga kepada seluruh warga sekolah dan juga lingkungan masyarakat di sekitar SMP Negeri 13. Dampak positif yang ditampilkan dari program adiwiyata mandiri di sekolah dalam 
meningkatkan kepedulian peserta didik terhadap lingkungan membuat seluruh warga sekolah mendapatkan manfaatnya. Antara lain seperti, ruang hijau yang terbuka membuat sekolah tersebut tampak nyaman dan asri sehingga pada proses pembelajaran menjadi lebih kondusif bagi peserta didik dan juga guru.

Hal ini diperkuat dengan yang dikemukakan oleh Poortinga (2004, hlm. 70) is relevant to distinguish between different measure of environmental impact and different types of environmental intent. Kemudian Isnaeni menambahkan (2014, hlm. 141) bahwa dampak langsung dari program adiwiyata adanya kesadaran warga sekolah untuk mencintai dan menjaga lingkungan hidup serta merawatnya untuk kepentingan diri sendiri, lingkungan sekitar dan bagi kelestarian ekosistem di bumi. Selaras menurut Susilastri (2015, hlm. 269) bahwa sekolah adiwiyata menumbuhkan kesadaran, kepedulian, tanggung jawab. Berdasarkan hasil deskripsi mengenai program adiwiyata mandiri di sekolah dalam meningkatkan kepedulian peserta didik terhadap lingkungan, didapat bahwa program adiwiyata mandiri mengaja peserta didik untuk peduli terhadap lingkungan salah satu nya dnegan melakukan pembibitan, pengomposan, penghijauan yang dilakukan bersa dengan para guru .

Guru disini secara tidak langsung ikut mengajarkan kepada peserta didik akan pentingnya lingkungan yang asri dan nyaman yang dapat membuat warga sekolah menjadi nyaman dalam melakukan kegiatan apapun salah satunya belajara. Bukan hanya kepedulian peserta didik terhadap lingkungan, tapi disatu sisi juga kegiatan yang dilakukan bersama antara peserta didik dengan guru turut menciptakan budaya gotong royong antara guru dengan peserta didik. Selanjutnya juga guru secara tidak langsung tetang memberikan contoh dengan tindakan yang dapat dilihat langsung bahkan ditiru oleh peserta didik mengenai kegiatan dari program adiwiyata mandiri.

Sehingga dapat disimpukan bahwa program adiwiyata mandiri di sekolah dalam meningkatkan kepedulian peserta didik terhadap lingkungan antara lain dengan cara selalu memberikan contoh secara langsung, dan juga melakukan habituasi baik itu di luar atau di dalam kelas. Salah satu cara yang dilakukan antara lain melakukan pembibitan tanaman, penghijauan dan juga melakukan pengomposan.

\section{Implementasi Program Adiwiyata Mandiri melalui pembelajaran PKn dalam meningkatkan kepedulian peserta didik terhadap lingkungan}

Berdasarkan data yang di peroleh peneliti dari lapangan, melalui studi dokumentasi dan wawancara bahwa implementasi program adiwiyata mandiri melalui pembelajaran PKn dalam meningkatkan kepedulian peserta didik terhadap lingkungan, dapat dilihat dari bagaimana program adiwiyata mandiri ini dintegrasikan dalam setiap mata pelajaran yang ada termasuk mata pelajaran PKn. Dari observasi yang didapat oleh peneliti, menegaskan bahwa, program adiwiyata mandiri ini terintegrasi kedalam seluruh mata pelajaran termasuk mata pelajaran $\mathrm{PKn}$, Hal ini juga menegaskan bahwa program adiwiyata juga turut dimasukkan kedalam RPP mata pelajaran PKn tapi harus sesuai dengan materi yang akan diajarkan pada proses pembelajaran kelas.

Selanjutnya,

untuk mengimplementasikan program adiwiyata mandiri melalui pembelajaran PKn dalam meningkatkan kepedulian peserta didik terhadap lingkungan. Selain di integrasikan dalam mata pelajaran, diperlukan juga pelaksanaan didalam pembelajaran $\mathrm{PKn}$ untuk meningkatkan kepedulian peserta didik.

Selanjutnya dari implementasi
program adiwiyata mandiri melalui pembelajaran PKn, dapat melihat juga dari peran serta guru dalam mewujudkan program adiwiyata mandiri pada pembelajaran PKn untuk meningkatkan kepedulian peserta didik terhadap lingkungan.Implementasi program adiwiyata mandiri melalui pembelajaran PKn dalam meningkatkan kepedulian 
peserta didik terhadap lingkungan dapat dilihat dari segi materi yang diberikan oleh guru. Seperti hal nya dengan penjabaran diatas yang mengemukakan bahwa program adiwiyata mandiri terintegrasi kedalam seluruh mata pelajaran yang mana PKn juga termasuk kedalam mata pelajaran yang terintegrasi dkedalam program adiwiyata mandiri. Pada mata pelajaran PKn sendiri guru senantiasa memasukan unsur berwawasan lingkungan tersebut kedalam RPP yang akan diselaraskan kedalam proses pembelajaran, materi yang di berikan kepada peserta didikpun disesuaikan dengan progam adiwiyata mandiri yang akan diintegrasikan.

Dapat ditarik kesimpulan bahwa untuk mengimplementasikan program adiwiyata mandiri melalui materi pembelajaran PKn, guru dengan seksama memberikan contoh dan juga menjelaskan berdasarkan kesesuaian dari materi matapelajaran PKn karena, guru juga melihat materi yang di berikan kepada peserta didik berkaitan program adiwiyata mandiri. Guru juga biasanya menyisipkan baik itu diawal, pertengahan atau diakhir dari proses pembelajaran untuk mengintegrasikan program adiwiyata mandiri. Tetapi dari segi materi pembelajaran guru melihat terlebih dahulu materi yang akan di bahas, apakah sesuai atau tidak dari program adiwiyata mandiri. Namun, dengan materi yang memang tidak memiliki kesesuaian dari program adiwiyata mandiri guru hanya mengintegrasikannaya lewat awal ataupun akhir pembelajaran dengan cara mengingatkan kepada peserta didik. Kemudian diakhir proses pembelajaran guru senantiasa bersama dengan peserta didik mengaplikasikan materi yang telah diajarkan dan terintegrasi dengan program adiwiyata mandiri.

Berdasarkan observasi dan juga wawancara yang dilakukan oleh peneliti dilapangan didapati bahwa, implementasi program adiwiyata mandiri melalui metode pembelajaran $\mathrm{PKn}$ dalam meningkatkan kepedulian peserta didik terhadap lingkungan, kembali kepada cara guru mengintegrasikan program adiwiyata mandiri tersebut dan juga melihat dari isi materi yang disampaikan pada proses pembelajaran dikelas. Hal ini seperti yang dilihat peneliti pada saat melakukan obeservasi di lapangan didapat bahwa metode yang biasa dipakai oleh guru untuk menjelaskan materi pembelajaran $\mathrm{PKn}$, menggunakan metode ceramah bervariasi dan diskusi berkelompok.

Di dapat juga dari hasil observasi peneliti dilapangan yang masih berkenaan dengan implementasi program adiwiyata mandiri dapat dilihat dari sumber belajar pada pembelajaran PKn dalam meningkatkan kepedulian peserta didik terhadap lingkungan. Dapat diketahui bahwa sumber belajar dapat berupa buku dan juga LKS yang di berikan oleh guru kepada peserta didik guna memahami materi dari tujuan pembelajaran. Dan untuk pengimplementasian program adiwiyata mandiri melalui sumber belajar pada matapelajaran PKn, guru biasanya memberikan contoh yang berkaitan dengan program adiwiyata mandiri berdasarkan sumber belajar.

Kemudian melihat dari implementasi program adiwiyata mandiri melalui penilaian pembelajaran PKn dalam meningkatkan kepedulian peserta didik terhadap lingkungan, adapun yang peneliti dapat dari hasil observasi dilapangan bahwa penilaian yang dilakukan oleh guru pada proses pembelajaran dilihat dari sikap dan juga moral yang dilakukan oleh peserta didik. Dimana sikap dan perilaku yang dilakukan oleh peserta didik senantiasa dilihat dan diamati oleh guru-guru di SMP Negeri 13 Palembang. Selain dari nilai akademis yang dinilai oleh guru, penilaian sikap dan juga moral dilihat oleh guru untuk menilai perilaku peserta didik.

Lebih lanjut lagi berdasarkan hasil dari data studi observasi, wawancara dan dokumentasi yang dilakukan oleh peneliti di lapangan di dapati bahwa, implementasi program adiwiyata mandiri melalui pembelajanran PKn dalam meningkatkan kepedulian peserta didik terhadap 
lingkungan dapat dilihat dari pelaksanaan, peran serta guru dan bagaimana implementasi program adiwiyata mandiri melalui materi, metode, media, sumber dan juga penilaian pembelajaran PKn dalam meningkatkan kepedulian peserta didik terhadap lingkungan. Seperti halnya ketika pengintegrasian program adiwiyata mandiri dalam materi pembelajaran, maka setelah proses pembelajaran guru mengaplikasikan materi yang telah diajarkan bersama dengan peserta didik.

Hal lainnya pengimplementasian program adiwiyata mandiri melalui pembelajaran PKn dalam meningkatkan kepedulian peserta didik terhadap lingkungan antara lain seperti, pembacaan janji siswa mengenai kepedulian lingkungan setiap masuk proses pembelajaran PKn, pemeliharaan taman kelas yang dilakukan peserta didik dan kampanye hidup sehat dengan tidak makan makanan berpengawet dan penggunaan wadah makanan sendiri yang dilakukan oleh guru terhadap peserta didik guna mengupayakan kantin sehat.

Implementasi program adiwiyata amandiri melalui pembelajaran PKn dalam meningkatkan kepedulian lingkunan peserta didik. Didapatkan bahwa untuk pengimplementasian dari program adiwiyata ini dengan cara mengajak peserta didik untuk turut serta dalam penghijauan tanaman baik itu disekolah. Dan juga cara pengimplementasian program adiwiyata mandiri melalui pemebelajran PKn dalam dilihat dari proses pembelajaran yang dilakukan oleh guru. Dimulai dari awal, inti dan akhir dari proses pembelajaran, dari materi, metode, media, sumber dan penilaian untuk melihat pengimplementasian program adiwiyata mandiri.

Lebih lanjut lagi program adiwiyata mandiri terintegrasi kedalam seluruh matapelajaran termasuk PKn yang mana salah satu pemngimplementasian ini dengan cara mengintegrasikan program adiwiyata mandiri yang berwawasan lingkungan kedalam materi, metode, media, sumber dan penilaian menjadi salah satu cara pemngimplementasian program adiwiyata mandiri yang akan di ajarkan kepada peserta didik. Winarno (2013, hlm. 25) materi pembelajaran secara garis besar terdiri atas pengetahuan, sikap dan keterampilan yang harus dipelajari peserta didik dalam rangka mencapai kompetensi yang telah ditentukan. Maka dari itu guru senantiasa menghubungkan atau mengintegrasikan dengan apik program adiwiyata mandiri dalam proses pembelajaran dengan cara memberikan contoh baik secara langsung ataupun tidak kepada peserta didik.

$$
\text { Menambahkan dari yang }
$$

dikemukakan Pusat Pelaksanaa Pendidikan Karakter Puskurbuk (2011, hlm. 34) dapat dipahami bahwa nilai-nilai yang terkandung terintegrasi pada semua mata pelajaran khususnya PKn antara lain pengembangan nilai peduli lingkungan, sejalan dengan yang diungkapkan oleh Iningsih (2013, hlm. 10) menjelaskan bahwa pembelajaran dengan pendekatan proses berbasis lingkungan merupakan faktor internal dalam mengelola proses pembelajaran kelas, sehingga mampu meningkatkan hasil menulis dan sikap peduli lingkungan baik secara bersama-sama maupun terpisah. Pengimplementasian dari program adiwiyata mandiri melalui pembelajaran PKn dalam meningkatkan kepedulian peserta didik terhadap lingkungan, bukan hanya dengan memberikan contoh secara langsung atau mengingatkan saja. Tapi, terlebih dengan pengintegrasian materi dalam mata pelajaran PKn kemudian diaplikasikan kedalam kehidupan sehari hari, selanjutnya pada awal pelaksanaan pembelajaran peserta didik mengucapkan janji siswa yang isinya berkaitan dengan kepedulian lingkungan, selanjutnya peserta didik mengimplementasikan program adiwiyata dengan memilihara taman kelas serta kampanye hidup sehat dengan tidak makan makanan berpengawet dan penggunaan wadah makanan sendiri yang dilakukan oleh guru terhadap peserta didik guna mengupayakan kantin sehat.

$$
\text { Johansson (2011, hlm. 109) }
$$
mengungkapkan bahwa School have long 
been seen as institutions for preparing children for life, both academically and as moral agents in society. In order to become capable, moral citizens, children need to be provided with opportunities to learn moral values. Sekolah menjadi tempat dimana mengupayakan agar peserta didik memiliki sikap dan juga tindakan yang memiliki upaya untuk mecegah kerusakan pada lingkungan sekitar, memperbaiki dan merevitalisasi kerusakan alam yang telah terjadi. Menambahakan menurut Iskandar (2014, hlm. 228) bahwa pendidikan lingkungan sekolah adalah pendidikan yang diperlukan untuk memperkuat nilai-nilai yang telah diberikan oleh keluarga. Kemudian dijabarkan menurut Desfandi (2015, hlm. 31) bahwa sekolah harus menjadi model dalam mewujudkan lingkungan yang sehat dan nyaman serta menjadi model dalam mewujudkan warga sekolah yang peduli dan berbudaya lingkungan. Kepedulian terhadap lingkungan hidup juga ditunjukkan melalui pengetahuan sikap dan tindakan (Wulandari, 2016, hlm. 76). Hal ini sesuai dengan hasil deskripsi penelitian bahwa sikap peserta didik dalam mengimplementasikan program adiwiyata mandiri melalui pembelajaran PKn dapat tercermin dari tingkah laku peserta didik disekolah dalam mengaplikasikan semua materi pada proses pelaksanaan pembelajaran.

Sehingga dapat disimpulkan bahwa implementasi program adiwiyata mandiri melalui pembelajaran PKn dalam meningkatkan kepedulian peserta didik terhadap lingkungan terintegrasi kedalam seluruh mata pelajaran yang ada di SMP Negeri 13 kota Palembang. Salah satunya mata pelajaran $\mathrm{PKn}$, dimana dalam proses pembelajaran di dalam materinya guru harus menyisipkan atau mengintegrasikan program adiwiyata mandiri yang berwawasan lingkungan tetapi dalam proses pembelajaran guru melihat terlebih dahulu kecocokan dari materi dengan program adiwiyata tersebut. Bukan hanya dalam proses pembelajaran $\mathrm{PKn}$, setiap awal hingga akhir pembelajaran guru selalu memberikan contoh secaa langsung ataupun tidak langsung serta guru selalu mengingatkan kepada peserta didik agar dapat peduli tehadap lingkungan, bukan hanya di dalam kelas tetapi juga dilingkungan sekolah dan sekitar masyarakatnya.

Kemudian pengimplementasian lain seperti pembacaan janji siswa mengenai kepedulian lingkungan setiap masuk proses pembelajaran $\mathrm{PKn}$, pemeliharaan taman kelas yang dilakukan peserta didik dan kampanye hidup sehat dengan tidak makan makanan berpengawet dan penggunaan wadah makanan sendiri yang dilakukan oleh guru terhadap peserta didik guna mengupayakan kantin sehat. Menjadi beberapa cara dalam mengimlementasikan program adiwiyata mandiri melalui pembelajaran PKn dalam meningkatkan kepedulian peserta didik terhadap lingkungan.

\section{SIMPULAN DAN SARAN}

Berdasarkan hasil temuan yang telah dijabarkan oleh peneliti pada pembahasan, oleh karena itu dapat disimpulakan bahwa peran program adiwiyata mandiri dalam meningkatkan kepedulian lingkungan peserta didik (Studi Kasus Di SMP Negeri 13 Kota Palembang) dapat meningkatkan kepedulian lingkungan peserta didik. Adapun temuan yang ditunjukkan dilapangan bahwa Program adiwiyata mandiri telah menjadi suatu program yang bermanfaat bagi seluruh peserta didik di SMP Negeri 13 kota Palembang. Dimana program adiwiyata mandiri, merupakan program yang berwawasan lingkungan sesuai dengan visi SMP Negeri 13 kota Palembang dapat mengajarkan peserta didik untuk turut serta peduli terhadap lingkungan baik itu lingkungan disekitar kelas, sekolah ataupun dilingkungan sekitar mereka atau masyarakat.

Adapun upaya, cara dan pengimplementasian yang di gunakan untuk meningkatkan kepedulian peserta didik ialah dengan cara guru yang tidak bosanbosannya untuk mengingatkankan peserta 
didik, memberi contoh secara langsung atau pun tidak langsung menjadi usaha yang dilakukan guru khususnya juga dalam proses pembelajaran PKn untuk meningkatkan kepedulian lingkungan peserta didik. Baik itu dari awal, inti hingga akhir pembelajaran. Baik itu dalam materi, metode, media, sumber dan juga penilaian yang dilakukan oleh guru PKn untuk melihat bagaimana kepedulian lingkungan peserta didik dapat meningkat. Dan juga melihat dari antusiasme peserta didik untuk melaksanakan program adiwiyata mandiri antara lin berupa penghijauan tanaman, pemilahan sampah dan juga ikut serta dalam piket sekolah yang menajdi salah satu tindakan untuk meningkatkan kepedulian peserta didik.

$$
\text { Meskipun di lapangan banyak }
$$
didapati kendala baik itu secara eksternal ataupun internal yaitu dari dalam guru itu sendiri, tetapi manfaat dari program adiwiyata mandiri program yang berwawasan lingkungan tidak hanya kepada peserta didik tetapi kepada seluruh guru di SMP Negeri 13 beserta staffnya. Peran program ini memberikan dampak yang signifikan kepada peserta didik utnuk selalu peduli dimanapun danjuga kapanpun berkenan dengan lingkungan. Karena pada dasarnya kepedulian lingkungan merupakan nilai karakter dari delapan belas karakter yang harus ditanamkan dan juga dikembangkan untuk peserta didik.

Program Adiwiyata Mandiri di sekolah dalam meningkatkan kepedulian lingkungan peserta didik, dapat dilihat dari upaya yang dilakukan oleh SMP Negeri 13 kota Palembang. Salah satu upaya yang dilakukan oleh guru lain dengan mengingatkan dan juga memberikan contoh dari program adiwiyata mandiri tersebut kepada peserta didik. Tindakan yang digunakan dalam program adiwiyata mandiri untuk meningkatkan kepedulian lingkungan peserta didik antara lain dengan mengikutsertakan peserta didik dalam kegiatannya antara lain ikut melaksanakan penghijauan tanaman, dapat melakukan pemilahan sampah, melakukan pengomposan dan dapat memanfaatkan penggunaan lahan yang minim.

\section{DAFTAR PUSTAKA}

Al Muchtar, S. (2015). Dasar Penelitian Kualitatif. Bandung: Gelar Pustaka Mandiri.

Arikunto, S. (2011). Dasar-dasar Evaluasi Pembelajaran. Jakarta: Bumi Aksara.

Cresswell, J. (2010). Research Design Pendekatan Kualitatif, Kuantitatif, dan Mixed. Yogyakarta: Pustaka Pelajar.

Daryanto dan Suryatri. (2013). Implementasi Pendidikan Karakter di Sekolah. Yogjakarta: Gava Media

Fitri, A. (2012). Reinventing Human Character: Pendidikan Karakter Berbasis Nilai Dan Etika di Sekolah. Yogyakarta: Ar- Ruzz Media.

Hamzah, S. (2013). Pendidikan Lingkungan. Bandung: Refika Aditama.

Iskandar, Z. (2013). Psikologi Lingkungan. Bandung: Refika Aditama.

Kementerian Lingkungan Hidup dengan Kementerian Pendidikan dan Kebudayaan. (2012). Buku Panduan Adiwiyata; Sekolah Peduli dan Berbudaya Lingkungan. Jakarta.

Miles, M dan Huberman, A. (1992). Analisis Data Kualitatif. Jakarta: Penerbit Universitas Indonesia (UI-Press).

Moleong, J. (2007). Metodelogi Kualitatif. Bandung: CV. Remadja Karya.

Sapriya dan Wahab, A. (2011). Teori dan Landasan Pendidikan

Kewarganegaraan. Bandung: Alfabeta.

Sugiyono. (2006). Metode Penelitian Kuantitatif, Kualitatif dan $R \& D$. Bandung: Alfa Beta.

Sukmadinata, N. (2012). Metode Penelitian Pendidikan. Bandung: PT. Remaja Rosdakarya. 
Citizenship Jurnal Pendidikan Pancasila dan Kewarganegaraan Vol 5 No 1 April 2017, hal 32-41 Avaliable online at : http://e-journal.unipma.ac.id/index.php/citizenship p-ISSN: 2302-433Xp e-ISSN 2579-5740

Sukardi. (2004). Metodologi Penelitian Pendidikan Kompetensi dan Praktiknya. Jakarta: PT. Bumi Aksara.

Winarno. (2013). Pembelajaran Pendidikan Kewarganegaraan: Isi, Strategi dan Penilaian. Jakarta : PT. Buku Aksara.

\section{Sumber dari Jurnal Internasional dan} Nasional:

Desfandi, dkk. (2015). Mewujudkan Masyarakat Berkarakter Peduli Lingkungan Melalui Program Adiwiyata Mandiri. SOSIO DIDAKTIKA: Social Science Educational Journal, 2(1), Hlm. 3137

Dutcher, D. (2007). Connectivity with Nature as a Measure of Environmental Values. SAGE; Environmental and Behavior. 39(4). Hlm. 474-493

Iningsih, W I dkk, (2013). Pengaruh Implementasi Pendekatan Proses Berbasis Lingkungan Terhadap Hasil Belajar Menulis dan Sikap Peduli Lingkungan Siswa Kelas V MIN Banyubiru Negara. e-journal Program Pascasarjana Universitas Pendidikan Ganesha; Jurusan Pendidikan Dasar. 3(3). HIm. 1-10

Parwono, dkk. (2013). Penerapan Model Problem Based Learning untuk Mengembangkan Kepedlian Sosial dan Lingkungan Hidup Siswa. Jurnal Studi Sosial Program Pascasarjana P-IPS. 1(3). Hlm. 1-15 Poortinga, W dkk. (2004). Values, Environmental concern, and Environmental Behavior (A Study Into Household Energy Use). SAGE Publication: Environment and Behavior. 36(1). Hlm. 70-93

Johansson, E. (2011). Practices for teaching moral values in the early years: a call for a pedagogy of participation. SAGE; Education, Citizenship and Social Justice. 6(2). Hlm. 109-124
Wulandari, R. (2016). Metode Kunjungan Lapangan untuk Menanamkan Kepedulian Terhadap Lingkungan Hidup. Jurnal Pedagogia. 5(1). Hlm. 67-80 